\title{
Antiproliferative activity in tumor cell lines, antioxidant capacity and total phenolic, flavonoid and tannin contents of Myrciaria floribunda
}

\author{
LUIS A.C. TIETBOHL ${ }^{1}$, ADRIANA P. OLIVEIRA ${ }^{2}$, RICARDO S. ESTEVES ${ }^{1}$, RICARDO \\ D.D.G. ALBUQUERQUE ${ }^{1}$, DIOGO FOLLY ${ }^{1}$, FRANCISCO P. MACHADO ${ }^{1}$, ARTHUR L. \\ CORRÊA ${ }^{1}$, MARCELO G. SANTOS ${ }^{3}$, ANA L.G. RUIZ ${ }^{4}$ and LEANDRO ROCHA ${ }^{1}$ \\ ${ }^{1}$ Laboratório de Tecnologia de Produtos Naturais, Faculdade de Farmácia, Universidade Federal \\ Fluminense, Rua Mário Viana, 523, Santa Rosa, 24241-000 Niterói, RJ, Brazil \\ ${ }^{2}$ Laboratório Multidisciplinar de Ciências Farmacêuticas, Faculdade de Farmácia, Centro de Ciências da Saúde, Universidade \\ Federal do Rio de Janeiro, Avenida Carlos Chagas Filho, 373, Ilha do Fundão, 21941-590 Rio de Janeiro, RJ, Brazil \\ ${ }^{3}$ Departamento de Ciências, Faculdade de Formação de Professores, Universidade Estadual do Rio de \\ Janeiro, Rua Dr. Francisco Portela, 1470, Patronato, 24435-005 São Gonçalo, RJ, Brazil \\ ${ }^{4}$ Divisão de Farmacologia e Toxicologia, Centro Pluridisciplinar de Pesquisas Químicas, Biológicas e \\ Agrícolas, Universidade de Campinas, Caixa Postal 6171, 13083-970 Campinas, SP, Brazil \\ Manuscript received on October 6, 2016; accepted for publication on January 6, 2017
}

\begin{abstract}
Myrciaria floribunda (H. West ex Willd.) O. Berg, Myrtaceae, is a native plant species of the Atlantic Rain Forest, from north to south of Brazil. The lyophilized ethyl acetate extract from the leaves of M. floribunda was investigated for its antiproliferative activity in tumor cell lines, antioxidant capacity and its total phenolic, flavonoid and tannin contents. Antiproliferative activity was tested in vitro against seven human cancer cells and against immortalized human skin keratinocytes line (HaCat, no cancer cell). Antioxidant activity was determined using 1-diphenyl-2-picrylhydrazyl (DPPH) radical scavenging and oxygen radical absorbing capacity (ORAC) assays and total phenolic, flavonoid and tannin contents were determined by spectrophotometric techniques. Ethyl acetate extract of $M$. floribunda exhibited antiproliferative activity against cancer cell lines with total growth inhibition (TGI) between 69.70 and $172.10 \mu \mathrm{g} / \mathrm{mL}$. For HaCat cell, TGI value was $213.60 \mu \mathrm{g} / \mathrm{mL}$. M. floribunda showed a strong antioxidant potential: $\mathrm{EC}_{50}$ of $45.89 \pm 0.42 \mu \mathrm{g} / \mathrm{mL}$ and $0.55 \pm 0.05 \mathrm{mmol} \mathrm{TE} / \mathrm{g}$ for DPPH and ORAC, respectively. Total phenolic content was $0.23 \pm 0.013 \mathrm{~g}$ gallic acid equivalents (GAE)/g extract and exhibited $13.10 \pm 1.60 \%$ of tannins content. The content of flavonoid was $24.08 \pm 0.44 \%$ expressed as rutin equivalents. These results provide a direction for further researches about the antitumoral potential of M. floribunda.
\end{abstract}

Key words: antioxidant, antiproliferative, flavonoids, Myrciaria floribunda, phenols.

\section{INTRODUCTION}

WHO's International Agency for Research on Cancer (IARC) estimates that 14.1 million new

Correspondence Adriana Passos Oliveira

E-mail: adrianapassos@pharma.ufrj.br cancer cases and 8.2 million cancer-related deaths occurred in 2012 (IARC 2013). The 2016 and 2017 annual estimation regarding Brazil foresees the emergence of approximately 600,000 new cancer cases (INCA 2015). 
According to Newman and Cragg (2016), the utilization of natural products and/or their novel structures, in order to discover and develop anticancer drugs is still alive and over $50 \%$ of the drugs in clinical trials for anticancer activity were isolated from natural sources or are related to them. Among the natural products, plant-derived compounds have been an important source of several clinically useful anti-cancer agents (Cragg and Newman 2005).

The Myrtaceae family has species typically of many Brazilian biomes with their floristic diversity. A great diversity of plants from this family has been employed for medicinal purposes by Brazilian's population (Cruz and Kaplan 2004). Some genus of this family were studied for its antiproliferative activity (Apel et al. 2006, Levy and Carley 2012, Annadurai et al. 2012, Kiruthiga et al. 2011). The Myrciaria genus was reported to show antiproliferative activity against tumor cell lines (Leite-Legatti et al. 2012, Wang et al. 2014).

Myrciaria floribunda (H. WEST ex Willd) O. Berg, popularly known as "camboim", "jabuticabinha", "murta", "duque", "goiabarana" and "araçazeiro" is native to Brazil and is distributed throughout the Atlantic Forest biome (Sobral et al. 2015). Essential oil from M. floribunda has been reported to be rich in terpenoid compounds and biological activities such as antimicrobial, anticholinesterasic, antitumoral and insecticide (Ramos et al. 2010, Tietbohl et al. 2012, 2014, Apel et al. 2006).

Despite studies about essential oils, chemical analysis and biological activities of the leaves of $M$. floribunda remain scare in the literature. Only one previous study with $M$. floribunda leaves reported that its ethyl acetate extract has phenolic compounds and the flavonoid myricetin-3-galoctoside was identified as one of the main compounds (Tietbohl 2012). As flavonoids are known to be anticancer and antioxidant agents (Batra and Sharma 2013, Weng and Yen 2012), this prompted us to evaluate the antiproliferative activity in tumor cell lines and to determine the antioxidant capacity and the contents of total phenolic, flavonoids and tannins of the ethyl acetate extract from the leaves of $M$. floribunda.

\section{MATERIALS AND METHODS}

\section{PLANT MATERIAL}

Three specimens of Myrciaria floribunda (H.West ex Willd.) O.Berg were collected in Restinga of Jurubatiba National Park at Carapebus City (22 $2^{\circ} 12^{\prime} 58.2^{\prime \prime} \mathrm{S}-41^{\circ} 35^{\prime} 00.0^{\prime} \mathrm{W}, 22^{\circ} 13^{\prime} 3.3^{\prime \prime} \mathrm{S}$ -

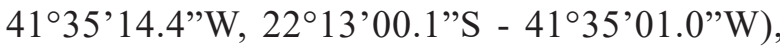
Rio de Janeiro State, Brazil, on March 10, 2014. The plant was identified by Dr. Marcelo Guerra Santos. A voucher specimen has been deposited under the registration number RFFP 13.789 at the Herbarium of the Faculdade de Formação de Professores, Universidade do Estado do Rio de Janeiro, Brazil.

\section{PLANT EXTRACTS}

The air-dried $\left(35^{\circ} \mathrm{C}, 24 \mathrm{~h}\right.$ under air circulation) leaves $(5000 \mathrm{~g})$ were powdered and exhaustively extracted by percolation at room temperature with ethanol $(96 \% \mathrm{v} / \mathrm{v})$. After evaporation under reduced pressure $\left(35^{\circ} \mathrm{C}\right)$, the hydroethanolic extract $(1087$ g) was resuspended in $3000 \mathrm{~mL}$ of ethanol $(90 \%$ $\mathrm{v} / \mathrm{v})$ and then partitioned with hexane $(3 \times 1.0 \mathrm{~L})$. The ethanol-soluble fraction was evaporated under reduced pressure, suspended in $1.0 \mathrm{~L}$ distilled water and then partitioned with dichloromethane $(0.5 \mathrm{~L}$ $\mathrm{x} 3)$, ethyl acetate $(0.5 \mathrm{~L} \times 3)$ and $n$-butanol (0.5 $\mathrm{L} \times 3$ ) successively to provide $n$-hexane (212.6 g), dichloromethane $(151.5 \mathrm{~g})$, ethyl acetate $(181.5 \mathrm{~g})$ and $n$-butanol (145.4 g) soluble fractions. The ethyl acetate extract was lyophilized for further analysis.

\section{ANTIPROLIFERATIVE ASSAY}

Human tumor cell lines U251 (glioma), UACC-62 (melanoma), MCF7 (breast), NCI-H460 (lung, non- 
small cells), PC-3 (prostate), OVCAR-3 (ovary) and HT29 (colon) were kindly provided by National Cancer Institute at Frederick MA-USA (NCI). In addition, a normal cell line (HaCat, immortalized human skin keratinocytes) was used. Stock cultures were grown in medium containing 5 mL RPMI 1640 (GIBCO BRL) supplemented with 5\% fetal bovine serum. Peniciline:streptomicine mixture (1000 UI/ $\mathrm{mL}: 1000 \mu \mathrm{g} / \mathrm{mL}, 1 \mathrm{~mL} / \mathrm{LRPMI} 1640$ ) was added to experimental cultures. Inoculation densities used were as follows: $\mathrm{U} 251\left(4.0 \times 10^{4}\right.$ cells $\left./ \mathrm{mL}\right), \mathrm{UACC}$ $62\left(4.0 \times 10^{4}\right.$ cells $\left./ \mathrm{mL}\right)$, MCF7 $\left(6.0 \times 10^{4}\right.$ cells $\left./ \mathrm{mL}\right)$, NCI-H460 (4.0x $10^{4}$ cells $\left./ \mathrm{mL}\right), \mathrm{PC}-3\left(5.0 \times 10^{4}\right.$ cells $/ \mathrm{mL})$, OVCAR-3 (7.0x $10^{4}$ cells $\left./ \mathrm{mL}\right)$, HT29 $\left(4.0 \times 10^{4}\right.$ cells $\left./ \mathrm{mL}\right)$ and $\mathrm{HaCaT}\left(4.0 \times 10^{4}\right.$ cells/ $\mathrm{mL})$. Cells in 96 -well plates $(100 \mu \mathrm{L}$ cells/well $)$ were exposed to different sample concentrations in DMSO/RPMI $(0.25,2.5,25$, and $250 \mu \mathrm{g} / \mathrm{mL})$ and incubated at $37{ }^{\circ} \mathrm{C}$ with $5 \% \mathrm{CO}_{2}$ atmosphere for $48 \mathrm{~h}$. Final DMSO concentration did not affect cell viability. Afterwards, cells were fixed with $50 \%$ trichloroacetic acid and cell proliferation was determined by spectrophotometric quantification (540 nm wavelength) of cellular protein content using sulforhodamine B assay. Doxorubicin chloridrate $(0.1 \mathrm{mg} / \mathrm{mg}$; Europharma) was used as a positive control. Three measurements were obtained: at time zero (T0, at the beginning of incubation) and $48 \mathrm{~h}$ post-incubation for compound free $(\mathrm{C})$ and tested $(\mathrm{T})$ cells. Cell proliferation was determined according to the equation $100 \times[(\mathrm{T}-$ $\left.\left.\mathrm{T}_{0}\right) / \mathrm{C}-\mathrm{T}_{0}\right]$, for $\mathrm{T}_{0}<\mathrm{T} \leq \mathrm{C}$, and $100 \times\left[\left(\mathrm{T}-\mathrm{T}_{0}\right) / \mathrm{T}_{0}\right]$, for $\mathrm{T} \leq \mathrm{T}_{0}$ and a concentration-response curve for each cell line was plotted using software Origin 8.0 (OriginLab Corporation). For the concentrationresponse curve for each cell line, TGI (concentration that produces $100 \%$ of cell growth inhibition or cytostatic effect) value was determined through non-linear regression analysis using the software Origin $8.0^{\circledR}$ (OriginLab Corporation) (Monks et al. 1991, Shoemaker 2006).
OXYGEN RADICAL ABSORBING CAPACITY ASSAY (ORAC)

The evaluation was performed using a 96well microplate reader (Fluostar Optima - Fluoroluminometer, BMG Labtech). The antioxidant capacity of the ethyl acetate extract from leaves was measured by fluorescence decay of fluorescein (Sigma), induced by 2,2' -azobis (2-amidinopropane) dihydrochloride (AAPH). Measurements were done by following time course of the fluorescence decay, in order to estimate antioxidant capacity. Using Trolox as standard, a calibration curve was generated using the net area under the curve AUC (AUCTrolox - AUCblank). ORAC values were calculated using the linear regression and expressed as Trolox Equivalent (TE). TE = slope regression curve (sample) / slope regression curve (Trolox) (Huang et al. 2002). The experiments were realized in triplicate and acceptable $R^{2}$ was $\geq 0.95$.

\section{DPPH RADICAL SCAVENGING ASSAY}

Sample stock solution of the ethyl acetate extract $(1.0 \mathrm{mg} / \mathrm{mL})$ was diluted to final concentrations of $250,125,50,25,12.5$ and $6.25 \mu \mathrm{g} / \mathrm{mL}$ in methanol. One $\mathrm{mL}$ of a $0.3 \mathrm{mM} \mathrm{DPPH}$ ethanol solution was added to $2.5 \mathrm{~mL}$ of sample solutions of different concentrations and allowed to react at room temperature. After $30 \mathrm{~min}$, the absorbance values were measured at $518 \mathrm{~nm}$ wavelength and converted into the percentage antioxidant capacity (AA) using the following formula: AA $\%=100-$ [(Abs sample - Abs blank) x $100 /$ Abs control]. Methanol $(1.0 \mathrm{~mL})$ plus extract solution $(2.5 \mathrm{~mL})$ was used as a blank. DPPH solution $(1.0 \mathrm{~mL}$; $0.3 \mathrm{mM}$ ) plus methanol $(2.5 \mathrm{~mL})$ was used as a negative control. The $\mathrm{EC}_{50}$ value was calculated by linear regression of plots where the abscissa represented the concentration of evaluated extract and the ordinate was related to average percent of antioxidant capacity (Mensor et al. 2001). The 
experiments were realized in triplicate with $\mathrm{R}^{2}=$ 0.99 and Trolox was used as an antioxidant control.

\section{DETERMINATION OF TOTAL FLAVONOIDS}

An ultraviolet spectrophotometric method was used for total flavonoid quantitation of the ethyl acetate extract of Myrciaria floribunda, as rutin equivalents, according to an adaptation of the method developed by Rolim et al. (2005). The concentration of total flavonoids was determined spectrophotometrically as rutin equivalents compared to the standard curve of rutin. Standard rutin was dissolved in $95.0 \%$ ethanol and $0.02 \mathrm{M}$ acetic acid (99:1) to concentrations of $12.5 ; 25.0$; $50.0 ; 75.0$ and $85.0 \mathrm{mg} / \mathrm{mL}$. The absorbance measurements were obtained at $360.0 \mathrm{~nm}$. The mixture of ethanol $95 \%$ and acetic acid $0.02 \mathrm{M}$ (99:1) was used as a solvent for the preparation of the sample solution. Analyses were performed in triplicates and the results are presented as mean \pm standard deviation ( $\% \mathrm{w} / \mathrm{w}, \pm$ s.d.).

\section{DETERMINATION OF TOTAL POLYPHENOLIC CONTENTS}

The total polyphenol content was determined by spectrophotometry, using gallic acid as a standard, according to the method described by Anesini et al. (2008). Briefly, $1.0 \mathrm{~mL}$ of the diluted sample extract in methanol $(200 \mu \mathrm{g} / \mathrm{mL})$ was transferred in duplicate to separate tubes containing $5.0 \mathrm{~mL}$ of a 1/10 dilution of Folin-Ciocalteu's reagent in water. Then, $4.0 \mathrm{~mL}$ of a sodium carbonate solution $(7.5 \% \mathrm{w} / \mathrm{v})$ was added. The tubes were then allowed to stand at room temperature for 60 min before the absorbance at $765 \mathrm{~nm}$ was measured against water. Results were expressed as grams of gallic acid equivalents (GAE) per gram of extract ( $g$ of GAE/g). The concentration of polyphenols in samples was derived from a standard curve of gallic acid ranging from 10 to $50 \mu \mathrm{g} / \mathrm{mL}$.

\section{DETERMINATION OF TANNINS}

Tannins were measured by protein precipitation assay with the use of hide powder method described for Eugenia uniflora (Myrtaceae) in the Brazilian Pharmacopoeia (Brasil 2010). The total tannin concentration was assayed by measuring at $715 \mathrm{~nm}$ the absorbance of the product formed with Folin-Denis reagent. Polyphenols unadsorbed on hide powder was determined from $10 \mathrm{~mL}$ of methanol solution of the ethyl acetate extract (200 $\mu \mathrm{g} / \mathrm{mL}$ ) with addition of $0.1 \mathrm{~g}$ hide powder (Sigma) vigorously mixed for $60 \mathrm{~min}$ and filtrated. The polyphenol adsorved in hide powder, calculated from the difference among polyphenol total and polyphenol unadsorbed, was derived from a five-point standard curve of pyrogallol (Sigma) ranging from 3 to $100 \mu \mathrm{g} / \mathrm{mL}$. The curves showed satisfactory linearity within the analyzed range $\left(\mathrm{R}^{2}\right.$ $>0.99$ ). Tannin content (\%) was determined as the ratio between the adsorbed polyphenol content and the initial concentration of sample (Macedo et al. 2013). Analyses were performed in triplicates and the results are presented as mean \pm standard deviation ( $\% \mathrm{w} / \mathrm{w}, \pm$ s.d. $)$.

\section{RESULTS AND DISCUSSION}

A range of $M$. floribunda extract concentration (from $0.25,2.5,25.0$ to $250.0 \mu \mathrm{g} / \mathrm{mL}$ ) was used to investigate the relative degree of growth inhibition against a series of cancer cell lines. Figure 1 demonstrates that $M$. floribunda showed a marked inhibition effect on cancer cells growth and it was not in a concentration-dependent manner.

Table I shows the results of the antiproliferative effect of $M$. floribunda against all cell lines with total growth inhibition (TGI) values between 69.70 and $172.10 \mu \mathrm{g} / \mathrm{mL}$. The cell line MCF-7 (breast cancer) was more susceptible with TGI value equal to $69.70 \mu \mathrm{g} / \mathrm{mL}$. This extract also showed cytostatic effect against U251 (glioma, TGI = 97.30 $\mu \mathrm{g} / \mathrm{mL}$ ), UACC-62 (melanoma, TGI = $101.60 \mu \mathrm{g} /$ 
Myrciaria floribunda

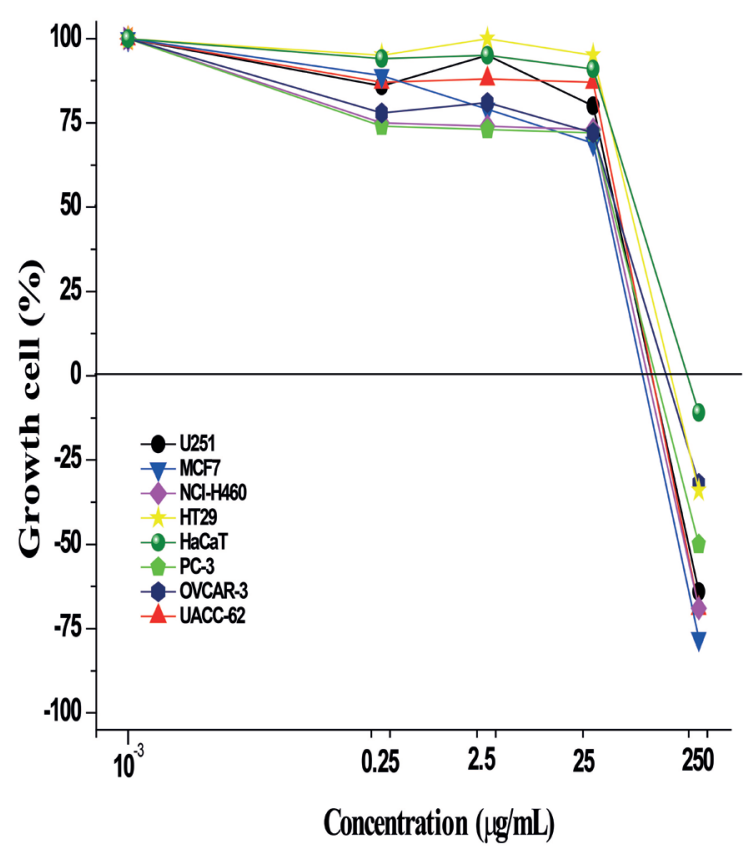

\section{Doxorrubicin}

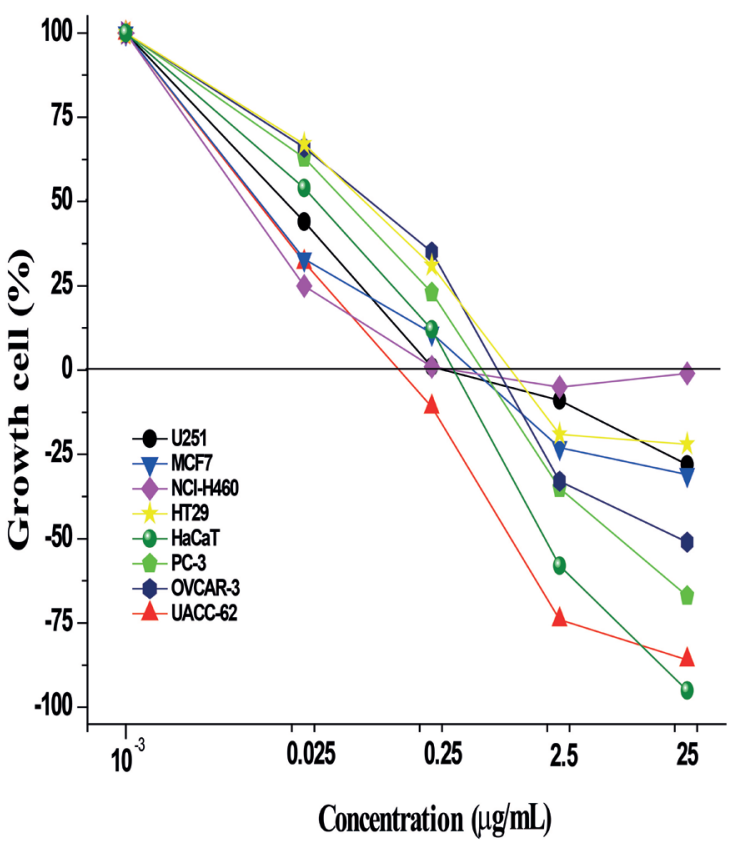

Figure 1 - Percentage of cell growth after $48 \mathrm{~h}$ treatment with different concentrations $(0.25,2.5,25 \mathrm{and} 250 \mu \mathrm{g} / \mathrm{mL})$ of the ethyl acetate extract from Myrciaria floribunda leaves and Doxorrubicin. Human tumor cell lines U251 (glioma), UACC62 (melanoma), MCF7 (breast), NCI-H460 (lung, non-small cells), PC-3 (prostate), OVCAR-3 (ovary) and HT29 (colon) and normal cell line (HaCat, immortalized human skin keratinocytes). Each point represents the mean and SD of three determinations. Continuous horizontal line: Total Growth Inhibition (TGI). TGI values (concentration eliciting $0 \%$ of cell proliferation) were determined through non-linear regression analysis; dose range tested $0.25-250 \mu \mathrm{g} / \mathrm{mL}$.

TABLE I

Antiproliferative activity of the ethyl acetate extract from the leaves of Myrciaria floribunda.

\begin{tabular}{ccc}
\hline \multirow{2}{*}{ Cells } & \multicolumn{2}{c}{${\text { TGI }(\boldsymbol{\mu g} / \mathbf{m L})^{\mathbf{a}}}$} \\
\cline { 2 - 3 } U251 & Doxorrubicin $^{\mathbf{b}}$ & M. floribunda $^{\mathbf{c}^{\mathbf{2}}}$ \\
UACC-62 & 0.94 & 97.3 \\
MCF-7 & 0.11 & 101.6 \\
NCI-H460 & 0.59 & 69.7 \\
PC-3 & 3.10 & 81.9 \\
OVCAR-03 & 0.61 & 100.9 \\
HT29 & 0.96 & 131.2 \\
HaCat & 2.10 & 172.1 \\
\hline
\end{tabular}

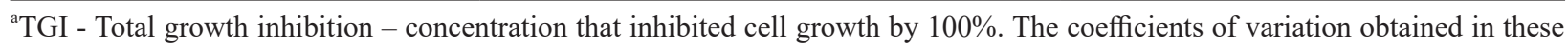
analyses were below to $5 \%$.

${ }^{\mathrm{b}}$ Positive control.

${ }^{\mathrm{c}}$ Ethyl acetate extract from the leaves of Myrciaria floribunda.

Cell lines: U251 (glioma), UACC-62 (melanoma), MCF7 (breast), NCI-H460 (lung, non-small cells), PC-3 (prostate), OVCAR-3 (ovary) and HT29 (colon), HaCat (immortalized human skin keratinocytes lines). 
$\mathrm{mL}$ ), NCI-H460 (lung, TGI $=81.90 \mu \mathrm{g} / \mathrm{mL}$ ), PC-3 (prostate, TGI $=100.90 \mu \mathrm{g} / \mathrm{mL}$ ), OVCAR-03 (ovary, TGI $=131.20 \mu \mathrm{g} / \mathrm{mL}$ ) and HT29 (colon, TGI $=172.10 \mu \mathrm{g} / \mathrm{mL}$ ). Although an excellent growth inhibiter of cancer cells, doxorubicin also affects the growth of non-tumor cells, for example, the ones from the HaCat cell line (Table I). In this regard, the assayed M. floribunda extract seems to be safer than doxorubicin since the toxicity to healthy cells was reached only at high concentrations. For example, the extract reaches a TGI higher than 210 $\mu \mathrm{g} / \mathrm{mL}$ for the HaCat cell line.

Some species from Myrciaria genus have been reported to show antiproliferative activity. The non-polar extract from the fruit peels of Myrciaria jaboticaba (Vell.) Berg demonstrated antiproliferative effects against leukemia (K-562) and prostate cancer cell (PC-3) (Leite-Legatti et al. 2012). Although the polar extract (ethanol) of $M$. jaboticaba peel, rich in polyphenol compounds, was not active against prostate cancer cell (PC-3) and ovary (OVCAR-3) and has shown concentrations that produce $50 \%$ of growth inhibition higher than $250.0 \mu \mathrm{g} / \mathrm{mL}$ (Leite-Legatti et al. 2012). In contrast, the polar extract of $M$. floribunda also rich in polyphenols has inhibited prostate (PC-3) and ovary (OVCAR-3) cells growth by $100 \%$ at concentrations of $100.90 \mu \mathrm{g} / \mathrm{mL}$ and $131.20 \mu \mathrm{g} /$ $\mathrm{mL}$, respectively. It has been reported that the deep purple of $M$. jaboticaba peel contains high concentrations of total and free ellagic acid (Abe et al. 2012), a polyphenol that has a powerful potential to suppress the proliferation of leukemia cells (Mertens-Talcott et al. 2003). In addition, $M$. jaboticaba also contains anthocyanins capable of suppressing neoplastic cell lines (Song et al. 2012).

A study with the polar extract (ethanol) of $M$. dubia leaves and pericarp showed antiproliferative activity against liver carcinoma cell line (Hep-G2) at $149.5 \pm 23.8$ and $124.0 \pm 12.3 \mu \mathrm{g} / \mathrm{mL}$, respectively (Tauchen et al. 2016). However, the polar extracts of M. dubia leaves and pericarp were not active against colon cell (HT29) and inhibited 50\% of the cell growth at a concentration higher $500.0 \mu \mathrm{g} / \mathrm{mL}$.

Flavonoid compounds extracted from $M$. cauliflora exhibited antiproliferative effect against HT29 and HCT116 colon cell lines (Reynertson et al. 2006). Several studies revealed flavonoids as potential antiproliferative and antioxidant agents (Batra and Sharma 2013, Weng and Yen 2012). Since a previous study with the ethyl acetate extract of $M$. floribunda leaves reported the flavonoid myricetin-3-galoctoside as one of the main compounds (Tietbohl 2012), this prompted us to determine the total phenolic, flavonoid and tannin contents and the antioxidant capacity of $M$. floribunda leaves in order to correlate chemical composition with antiproliferative effect. Table II presents the total phenolic, flavonoid and tannin contents determined by spectrophotometric techniques and the antioxidant capacity of the ethyl acetate extract of $M$. floribunda leaves by DPPH and ORAC assays.

The concentration of phenolic compounds in samples was derived from a standard curve of gallic acid $(y=0.0105 x+0.1136)$ with $R^{2}$ $=0.997$ (Table II). Total phenolic content of the ethyl acetate extract of $M$. floribunda leaves was $0.230 \pm 0.0136 \mathrm{~g}$ gallic acid equivalents $(\mathrm{GAE}) / \mathrm{g}$ extract. This value was higher than those reported in previous studies for Myrciaria spp., such as $M$. cauliflora fruits contains $0.031 \pm 0.1 \mathrm{~g} \mathrm{GAE} / \mathrm{g}$ (Reynertson 2007), M. jaboticaba fresh peel has $0.114 \mathrm{~g} \mathrm{GAE} / \mathrm{g}$ and the whole fruit shows 0.032 g GAE/g (Leite-Legatti et al. 2012) and M. dubia fruits fresh and dried exhibit 0.01176 and 0.01161 g GAE/g, respectively (Akter et al. 2011, Costa et al. 2013).

Tannin content of the ethyl acetate extract of M. floribunda leaves was $13.10 \pm 1.6 \%$ calculated from a calibration curve of pyrogallol $(\mathrm{y}=0.0131 \mathrm{x}$ +0.039 ) with $\mathrm{R}^{2}=0.999$ (Table II). The value obtained in this work was higher than those reported by Duarte et al. (2010) that showed a range of 3.0 
TABLE II

Total phenolic, flavonoid and tannin contents and antioxidant capacity by the DPPH and ORAC assays of the ethyl acetate extract from the leaves of Myrciaria floribunda.

\begin{tabular}{|c|c|c|c|}
\hline Assays & M. floribunda & Standard curve & $\mathbf{R}^{2}$ \\
\hline Phenol content $^{\mathrm{a}}$ (g of GAE/g) ${ }^{\mathrm{b}}$ & $0.23 \pm 0.013$ & $y=0.0105 x+0.1136$ & 0.997 \\
\hline $\operatorname{Tannin}^{\mathrm{a}}(\%)$ & $13.10 \pm 1.60$ & $y=0.0131 x+0.039$ & 0.999 \\
\hline Total flavonoids $^{\mathrm{a}}(\%)^{\mathrm{e}}$ & $24.08 \pm 0.44$ & $\mathrm{y}=0.0257 \mathrm{x}-0.0145$ & 0.998 \\
\hline DPPH assay, $\mathbf{E C}_{50}{ }^{\mathbf{a}}(\mu \mathrm{g} / \mathrm{mL})^{\mathbf{c}}$ & $45.89 \pm 0.42$ & $y=0.762 x+15.03$ & 0.998 \\
\hline ORAC $^{\mathrm{a}}(\mathrm{mmol} \mathrm{TE} / \mathrm{g})^{\mathrm{d}}$ & $0.55 \pm 0.05$ & $y=209.39 x+1236.76$ & 0.960 \\
\hline
\end{tabular}

${ }^{\mathrm{a}}$ Mean $(\% \mathrm{RSD}$, relative standard deviation) of triplicate assays.

${ }^{\mathrm{b}}$ Total phenolics data expressed as grams of gallic acid equivalents per gram (g of GAE/g) of extract.

${ }^{\mathrm{c}} \mathrm{DPPH}$ assay data expressed as EC50 (concentration that inhibited 50\% of the DPPH radical) in micrograms per milliliters ( $\mu \mathrm{g} /$ $\mathrm{mL})$.

${ }^{\mathrm{d} O R A C}$ data expressed as milimol of Trolox equivalents per gram (mmol of TE/g) of extract.

${ }^{\mathrm{e}}$ Total flavonoids data expressed as equivalent in rutin.

to $6.0 \%$ of tannin content for the ethanolic extract of $M$. cauliflora leaves cultivated in six sampling sites.

The total flavonoid content of the ethyl acetate extract, calculated from the calibration curve (y $=0.0257 \mathrm{x}-0.0145)$, was $24.08 \pm 0.44 \%$ or 240 $\mathrm{mg}$ rutin equivalents/g extract (Table II). The total flavonoid content of $M$. floribunda leaves was higher than those reported for other Myrtaceae species, such as Eugenia uniflora (8.43\%), Eugenia malaccensis (4.07\%), Eugenia brasiliensis (5.41\%), Eugenia beaurepaireana $(11.46 \%)$ and Eugenia umbelliflora (3.28\%) (Figueirôa et al. 2013, Magina 2008). This result may be explained because the species $M$. floribunda lives in areas of sandbank, which is a hostile environment for vegetal growth, and also its flavonoids antioxidant propriety protects the vegetal tissue from the extensive luminosity (Zuanazzi and Montanha 2004).

The ORAC value of the ethyl acetate extract was $0.55 \pm 0.05 \mathrm{mmolTE} / \mathrm{g}$ (Table II). Leite-Legatti et al. (2012) found ORAC values of $25.51 \mathrm{mmolTE} / \mathrm{g}$, $5.23 \mathrm{mmolTE} / \mathrm{g}$ and $1.51 \mathrm{mmolTE} / \mathrm{g}$ for the freezedried powdered extract, the fresh fruit peel and the whole fresh fruit of $M$. jaboticaba, respectively. The ORAC value found for M. floribunda leaves in the present study indicates a lower antioxidant potential compared to M. jaboticaba fruit peel and whole fresh fruit, although the differences in plant organs, extraction methods, solvents used and species could explain such variations.

The $\mathrm{EC}_{50}$ of the ethyl acetate extract in the DPPH assay was $45.89 \pm 0.42 \mu \mathrm{g} / \mathrm{mL}$ and the positive control Trolox was $2.95 \pm 0.05 \mu \mathrm{g} / \mathrm{mL}$ The best adjustment correlation was obtained using a linear model $\left(\mathrm{y}=0.762 \mathrm{x}+15.03 ; \mathrm{R}^{2}=0.998\right)$. Wang et al. (2014) worked with M. cauliflora and reported the $\mathrm{EC}_{50}$ of the ethanol extracts of peel, stem and seeds of 49.00, 17.00 and $27.00 \mu \mathrm{g} / \mathrm{mL}$, respectively, and the water extract of seed was 5.30 $\mu \mathrm{g} / \mathrm{mL}$. Einbond et al. (2004) found $\mathrm{EC}_{50}$ value of 6.2 $\pm 0.7 \mu \mathrm{g} / \mathrm{mL}$ for semi-purified aqueous fraction of M. cauliflora fruits by DPPH assay. These reported data indicate that Myrciaria spp. water extracts show a higher potent antioxidant activity compared to ethyl acetate extract. However, the chemical composition of aqueous extract is different than the alcohol extracts. Aqueous plant extracts often contain water-soluble antioxidant vitamins and sugars that may enhance the antioxidant activity (Degenhardt et al. 2000).

The ethyl acetate extract of $M$. floribunda leaves demonstrated antioxidant capacity and 
antiproliferative activity at the present study. Chemical assays of the extract revealed a high amount of total phenolic compounds, tannin $(13 \%)$ and flavonoids (24\%). Therefore, it is possible to assert that antioxidant capacity and antiproliferative activity of the extract are in suitable correlation with the chemical compound contents (total phenolic compounds, tannin and flavonoids), once these classes of compounds are known as potent antioxidants and anticancer agents (Einbond et al. 2004, Batra and Sharma 2013, Weng and Yen 2012, Wang et al. 1997). Moreover, Tietbohl (2012) reported that the main constituent of the ethyl acetate extract of $M$. floribunda leaves is myricetin-3-galoctoside, which has showed an antitumor-promoting activity, and could be related to the results observed in this study (Gao et al. 2002, Hayder et al. 2008).

\section{CONCLUSIONS}

Data obtained indicate an antiproliferative activity against tumor cell lines and antioxidant capacity in vitro of $M$. floribunda leaves extract. The cell line MCF-7 (breast cancer) was more sensitive to $M$. floribunda, while normal cells were less growthinhibited. The present study is the first report of total phenolic, flavonoid and tannin contents of $M$. floribunda leaves. Thus, this work contributes to the chemical and pharmacological knowledge of M. floribunda. Despite the promising results found here, further biological studies should be performed, including in vivo investigations, looking toward a medicinal use of this bioactive natural product.

\section{ACKNOWLEDGMENTS}

The authors are grateful to Conselho Nacional de Desenvolvimento Científico e Tecnológico (CNPq) and Fundação Carlos Chagas Filho de Amparo à Pesquisa do Estado do Rio de Janeiro (FAPERJ) for financial support.

\section{REFERENCES}

ABE LT, LAJOLO FM AND GENOVESE MI. 2012. Potential dietary sources of ellagic acid and other antioxidants among fruits consumed in Brazil: jabuticaba (Myrciaria jaboticaba (Vell.) Berg). J Sci Food Agric 92: 1679-1687.

AKTER S, OH S, EUN JB AND AHMED M. 2011. Nutritional compositions and health promoting phytochemicals of camu-camu (myrciariadubia) fruit: A review. Food Res Int 44: 1728-1732.

ANESINI C, FERRARO GE AND FILIP R. 2008. Total Polyphenol Content and Antioxidant Capacityof Commercially Available Tea (Camellia sinensis) in Argentina. J Agr Food Chem 56: 9225-9229.

ANNADURAI G, MASILLA BRP, JOTHIRAMSHEKAR S, PALANISAMI E, PUTHIYAPURAYI S AND PARIDA AK. 2012. Antimicrobial, antioxidant, anticancer activities of Syzygium caryophyllatum (L.) Alston. Int J Green Pharm 6: 285-288.

APEL MA, LIMA MEL, SOUZA A, CORDEIRO I, YOUNG MCM, SOBRAL MEG, SUFFREDINI IB AND MORENO PRH. 2006. Screening of the biological activity from essential oils of native species from the Atlantic rain forest (São Paulo - Brazil). PhOL 3: 376-383.

BATRA P AND SHARMA AK. 2013. Anti-cancer potential of flavonoids: recent trends and future perspectives. Biotech 3: 439-459.

BRASIL. 2010. Farmacopeia Brasileira, volume 2 / Agência Nacional de Vigilância Sanitária. Brasília: Anvisa.

COSTA AGV, GARCIA-DIAZ DF, JIMENEZ P AND SILVA PYIA. 2013. Bioactive compounds and health benefits of exotic tropical red-black berries. J Funct Foods 5 (2013): 539-549.

CRAGG GM AND NEWMAN DJ. 2005. Plants as a source of anti-cancer agents. J Ethnopharmacol 100: 72-79.

CRUZ AVM AND KAPLAN MAC. 2004. Uso medicinal de espécies das famílias Myrtaceae e Melastomataceae no Brasil. Floresta e Ambiente 11: 47-52.

DEGENHARDT A, KNAPP H AND WINTERHALTER P. 2000. Separation and purification of anthocyanins by highspeed countercurrent chromatography and screening for antioxidant activity. J Agr Food Chem 48: 338-343.

DUARTE AR, SANTOS SC, SERAPHIN JC AND FERRI PH. 2010. Environmental Influence on Phenols and Essential Oils of Myrciaria cauliflora Leaves. J Braz Chem Soc 21: 1672-1680.

EINBOND LS, REYNERTSON KA, LUO XD, BASILE MJ AND KENNELLY EJ. 2004. Anthocyanin antioxidants from edible fruits. Food Chem 84: 23-28.

FIGUEIRÔA E DE O, NASCIMENTO DA SILVA LC, DE MELO CM, NEVES JK, DA SILVA NH, PEREIRA VR AND CORREIA MT. 2013. Evaluation of antioxidant, immunomodulatory, and cytotoxic action of fractions 
from Eugenia uniflora L. and Eugenia malaccensis L.: correlation with polyphenol and flavanoid content. Scientific World Journal 2013: 125027.

GAO H, KUROYANAGI M, WU L, KAWAHARA N, YASUNO T AND NAKAMURA Y. 2002. AntitumorPromoting Constituents from Dioscorea bulbifera L. in JB6 Mouse Epidermal Cells. Biol Pharm Bull 25: 12411243.

HAYDER N, BOUHLEL I, SKANDRANI I, KADRI M, STEIMAN R, GUIRAUD P, MARIOTTE AM, GHEDIRA K, DIJOUX-FRANCA MG AND CHEKIR-GHEDIRA L. 2008. In vitro antioxidant and antigenotoxic potentials of myricetin-3-o-galactoside and myricetin-3-o-rhamnoside from Myrtus communis: Modulation of expression of genes involved in cell defence system using cDNA microarray. Toxicol in Vitro 22: 567-581.

HUANG D, OU B, HAMPSCH-WOODILL M, FLANAGAN J AND PRIOR R. 2002. High-throughput Assay of Oxygen Radical Absorbance Capacity (ORAC) Using a Multichannel Liquid Handling System Coupled with a Microplate Fluorescence Reader in 96-Well Format. J Agr Food Chem 50: 4437-4444.

INCA - INSTITUTO NACIONAL DE CÂNCER JOSÉ ALENCAR GOMES DA SILVA. 2015. Coordenação de Prevenção e Vigilância Estimativa 2016: incidência de câncer no Brasil/Instituto Nacional de Câncer José Alencar Gomes da Silva - Rio de Janeiro: INCA.

IARC - INTERNATIONAL AGENCY FOR RESEARCH ON CANCER. 2013. Latest world cancer statistics Global cancer burden rises to 14.1 million new cases in 2012: Marked increase in breast cancers must be addressed. World Health Organization.

KIRUTHIGA K, SARANYA J, EGANATHAN P, SUJANAPAL P AND PARIDA A. 2011. Chemical Composition, Antimicrobial, Antioxidant and Anticancer Activity of Leaves of Syzygiumbenthamianum (Wight ex Duthie) Gamble. JBAPN 1: 273-278.

LEITE-LEGATTI AV ET AL. 2012. Jaboticaba peel: Antioxidant compounds, antiproliferative and antimutagenic activities. Food Res Int 49: 596-603.

LEVY AS AND CARLEY S. 2012. Cytotoxic Activity of Hexane Extracts of Psidium Guajava L (Myrtaceae) and Cassia Alata L. (Caesalpineaceae) in Kasumi-1 and OV2008 Cancer Cell Lines. Trop J Pharm Res 11: 201207.

MACEDO JMM, SOUZA LGP, VALENZUELA VDC, OLIVEIRA AB, CASTILHO RO AND JÁCOME RLRP. 2013. Variação sazonal nos teores de flavonoides, taninos, e atividade antioxidante de Davilla rugosa Poir. Rev Ciênc Farm Básica Apl 34: 585-590.

MAGINA MDA. 2008. Estudo fitoquímico e biológico de espécies do gênero Eugenia. 178 f. Tese de Doutorado. Centro de Cências Físicas e Matemáticas. Programa de
Pós-Graduação em Química. Universidade Federal de Santa Catarina. Florianópolis.

MENSOR LL, MENEZES FS, LEITÃO GG, REIS AS, DOS SANTOS TC, COUBE CS AND LEITÃO SG. 2001. Screening of Brazilian plant extracts for antioxidant activity by the use of DPPH free radical method. Phytother Res 15: 127-130.

MERTENS-TALCOTT SU, TALCOTT ST AND PERCIVAL SS. 2003. Low concentrations of quercetin and ellagic acid synergistically influence proliferation, cytotoxicity and apoptosis in MOLT-4 human leukemia cells. J Nutr 133: 2669-2674.

MONKS A ET AL. 1991. Feasibility of a high-flux anticancer drug screen using a diverse panel of cultured human tumor cell lines. J Natl Cancer Inst 83: 757-766.

NEWMAN DJ AND CRAGG GM. 2016. Natural Products as Sources of New Drugs from 1981 to 2014. J Nat Prod 79: 629-661.

RAMOS MFS, DA-MONTEIRO SS, DA-SILVA VP, NAKAMURA MJ AND SIANI AC. 2010. Essential oils from Myrtaceae species of the Brazilian Southeastern maritime forest (Restinga). J Essent Oil Res 22: 109-1133.

REYNERTSON KA. 2007. Phytochemical analysis of bioactive constituents from edible Myrtaceae fruits. New York: Thesis-Graduate Faculty in Biology-City University of New York.

REYNERTSON KA, WALLACE AM, ADACHI S, GIL RR, YANG H, BASILE MJ, D'ARMIENTO J, WEINSTEIN IB AND KENNELLY EJ. 2006. Bioactive depsides and anthocyanins from jaboticaba (Myrciaria cauliflora). J Nat Prod 69: 1228-1230.

ROLIM A, MACIEL COM, KANEKO TM, CONSIGLIERI VO, SALGADO-SANTOS IMN AND VELASCO MVR. 2005. Validation assay for total flavonoids, as rutin equivalents, from Trichiliacatigua Adr. Juss. (Meliaceae) and Ptychopeta lumolacoides Bentham (Olacaceae) Commercial Extract. J AOAC Int 88: 1015-1019.

SHOEMAKER RH. 2006. The NCI60 human tumor cell line anticancer drug screen. Nat Rev Cancer 6: 813-823.

SOBRAL M, PROENÇA C, SOUZA M, MAZINE F AND LUCAS E. 2015. Myrtaceae in Lista de Espécies da Flora do Brasil. Jardim Botânico do Rio de Janeiro. Disponível em: <http://floradobrasil.jbrj.gov.br/jabot/floradobrasil/ FB171>. Access in: 29 Oct. 2015.

SONG NR, YANG H, PARK J, KWON JY, KANG NJ, HEO YS, LEE KW AND LEE HJ. 2012. Cyanidin suppresses neoplastic cell transformation by directly targeting phosphatidylinositol 3-kinase. Food Chem 133: 658-664.

TAUCHEN J ET AL. 2016. Phenolic composition, antioxidant and anti-proliferative activities of edible and medicinal plants from the Peruvian Amazon. Rev Bras Farmacogn 26: 728-737. 
TIETBOHL LAC. 2012. Estudo fitoquímico e biológico da espécie vegetal Myrciaria floribunda (H.West ex Willd.) O.Berg. Thesis (Master Degree). Faculdade de Farmácia. Universidade Federal Fluminense (UFF). (Unpublished).

TIETBOHL LAC ET AL. 2014. Laboratory evaluation of the effects of essential oil of Myrciaria floribunda leaves on the development of Dysdercus peruvianus and Oncopeltus fasciatus. Rev Bras Farmacogn 24: 316-321.

TIETBOHL LAC, LIMA BG, FERNANDES CP, SANTOS MG, SILVA FEB, DENARDIN ELG, BACHINSKI R, ALVES GG, SILVA-FILHO MV AND ROCHA L. 2012. Comparative study and anticholinesterasic evaluation of essential oils from leaves, stems and flowers of Myrciaria floribunda (H.West ex Willd.) O.Berg. Lat Am J Pharm 31: 637-641.
WANG H, CAO G AND PRIOR R. 1997. Oxygen radical absorbing capacity of anthocyanins. J Agr Food Chem 45: 304-309.

WANG WH, TYAN YC, CHEN ZS, LIN CG, YANG MH, YUAN SS AND TSAI WC. 2014. Evaluation of the Antioxidant Activity and Antiproliferative Effect of the Jaboticaba (Myrciaria cauliflora) Seed Extracts in Oral Carcinoma Cells. Biomed Res Int Volume 2014, Article ID 185946, 7 pages http://dx.doi.org/10.1155/2014/185946.

WENG CJ AND YEN GC. 2012. Flavonoids, a ubiquitous dietary phenolic subclass, exert extensive in vitro antiinvasive and in vivo anti-metastatic activities. Cancer Metastasis Rev 31: 323-351.

ZUANAZZI JAS AND MONTANHA JA. 2004. Flavonoides. In: Simões CMO, Schenkel EP, Gosmann G, Mello JCP, Mentz LA and Petrovick PR. Farmacologia: da planta ao medicamento. $5^{\text {a }}$ ed., UFRGS 23: 577-614. 